Tersedia online di: http://ejournal-balitbang.kkp.go.id/index.php/ma

\title{
KEMAMPUAN HIDUP DAN TUMBUH IKAN KEMURING, Striuntius lineatus (Duncker, 1904) ASAL PULAU BANGKA PADA TAHAP AWAL DOMESTIKASI
}

\author{
Wahyu dan Eva Prasetiyono\# \\ Jurusan Akuakultur, Universitas Bangka Belitung \\ Desa Balunijuk Kecamatan Merawang Kabupaten Bangka, Bangka Belitung
}

(Naskah diterima: 7 April 2021; Revisi final: 19 Mei 2021; Disetujui publikasi: 21 Mei 2021)

\begin{abstract}
ABSTRAK
Ikan kemuring, Striuntius lineatus (Duncker, 1904), merupakan salah satu ikan lokal yang berpotensi untuk dikembangkan menjadi ikan hias. Ikan ini tergolong sulit didapatkan akibat rusaknya habitat oleh aktivitas manusia. Ikan ini merupakan ikan yang rentan stres dan mudah mengalami kematian. Domestikasi adalah salah satu upaya mencegah terjadinya kepunahan terhadap populasi spesies yang terancam siklus hidupnya. Penelitian ini bertujuan menguji kemampuan hidup dan performa pertumbuhan ikan kemuring dalam akuarium, serta mengetahui kualitas air yang mendukung pemeliharaan ikan kemuring. Penelitian ini menggunakan metode eksperimen. Data dianalisis secara deskriptif kuantitatif. Untuk melihat hubungan antara sintasan dengan kualitas air dianalisis menggunakan analisis PCA. Hasil penelitian menunjukkan bahwa ikan kemuring mampu hidup dan tumbuh pada wadah akuakultur. Nilai sintasan, pertumbuhan bobot mutlak, panjang mutlak, dan laju pertumbuhan spesifik masing-masing sebesar $93,33 \pm 0,06 \%$ 1,70 $\pm 0,31 \mathrm{~g} ; 10,29 \pm 1,02 \mathrm{~mm}$; dan $0,96 \pm 0,19 \%$ bobot tubuh/hari. Nilai suhu, $\mathrm{pH}, \mathrm{DO}, \mathrm{TDS}, \mathrm{TAN}$, dan kesadahan untuk pemeliharaan ikan kemuring didapatkan nilai masing-masing sebesar $28,72 \pm 0,44^{\circ} \mathrm{C}$; $6,28 \pm 0,82 ; 5,81 \pm 0,77 \mathrm{mg} / \mathrm{L} ; 0,48 \pm 0,16 \mathrm{mg} / \mathrm{L} ; 2,50 \pm$ 1,01 mg/L; dan 106,67 \pm 55,73 mg/L. Berdasarkan analisis PCA, sintasan ikan kemuring di wadah pemeliharaan dipengaruhi oleh suhu, pH, DO, TAN, dan kesadahan.
\end{abstract}

\section{KATA KUNCl: ikan kemuring; sintasan; pertumbuhan; domestikasi}

ABSTRACT: Survival ability and growth performance of lined barb, Striuntius lineatus (Duncker, 1904), from Bangka Island in early stage of domestication. By: Wahyu and Eva Prasetiyono

Lined barb is one of the local fish from Bangka Island that can be developed as a farmed ornamental fish. The fish is now rarely found in the wild due to its extensive habitat destruction by human activities. The fish is also relatively easy to get stressed and died. Domestication offers a solution to prevent the extinction of this fish population. Therefore, this study aimed to examine the survival and growth performance and determine the optimum rearing condition of lined barb in an aquarium setting. This research was carried out as an experimental study. The collected data were analyzed descriptively. The relationship between survival and water quality was determined using PCA analysis. The results showed that lined barbs were able to survive and grow in the aquaculture rearing media. The values of survival rate, absolute weight growth, absolute length, and specific growth rate were $93.33 \pm 0.06 \% 1.70 \pm 0.31 \mathrm{~g}, 10.29 \pm 1.02 \mathrm{~mm}$, and $0.96 \pm 0.19 \%$ body weight/day, respectively. The average values of temperature, pH, DO, TDS, TAN, and hardness were $28.72 \pm 0.44^{\circ} \mathrm{C}, 6.28 \pm 0.82,5.81 \pm 0.77 \mathrm{mg} / \mathrm{L}, 0.48 \pm 0.16 \mathrm{mg} / \mathrm{L}, 2.50 \pm 1.01 \mathrm{mg} / \mathrm{L}$, $106.67 \pm 55.73 \mathrm{mg} / \mathrm{L}$, respectively. Based on the PCA analysis, the survival of lined barbs in aquaculture containers was influenced by temperature, $\mathrm{pH}, \mathrm{DO}, \mathrm{TAN}$, and hardness of its rearing media.

KEYWORDS: lined barb; survival rate; growth; domestication

\footnotetext{
\# Korespondensi: Jurusan Akuakultur, Universitas Bangka

Belitung. Desa Balunijuk Kecamatan Merawang

Kabupaten Bangka, Bangka Belitung

E-mail: evaintegral@gmail.com
} 


\section{PENDAHULUAN}

Beberapa jenis ikan lokal air tawar hidup di perairan Bangka dan berpotensi untuk dijadikan ikan hias. Ikan kemuring, Striuntius lineatus (Duncker, 1904), adalah salah satu jenis ikan lokal yang banyak ditemukan di perairan Bangka. Ikan kemuring berpotensi untuk dijadikan sebagai ikan hias karena memiliki corak warna yang menarik dan ukuran tubuh yang tidak terlalu besar. Menurut Said \& Hidayat (2015), nilai keindahan pada ikan hias dapat dilihat dari kekhasan pola warna, perilaku, dan bentuk tubuh. Ikan hias yang memiliki warna mencolok cenderung lebih diminati para akuakulturis.

Ikan kemuring banyak ditemukan di rawa dan sungai kecil yang jernih dan arus yang tidak terlalu deras. Ikan kemuring biasanya hidup bergerombol dan sering ditemukan hidup berdampingan dengan ikan seluang (Rasbora sp.). Keberadaan ikan kemuring di alam khususnya daerah Pulau Bangka, saat ini sudah semakin langka karena lingkungan habitat hidupnya sudah banyak rusak akibat pertambangan timah. Muslih et al. (2014) menyatakan bahwa aktivitas penambangan timah di sekitar aliran sungai berdampak pada ekosistem dan mengancam keanekaragaman hayati perairan seperti ikan. Ancaman tersebut akan memengaruhi perubahan struktur habitat alami ikan dan komposisi, serta distribusinya.

Ikan kemuring merupakan salah satu ikan lokal yang berpotensi untuk dikembangkan. Namun permasalahannya adalah ikan kemuring masih cukup sulit diadaptasikan pada wadah terkontrol dan rentan mengalami kematian. Beberapa upaya pemeliharaan yang dilakukan oleh masyarakat lokal Bangka menunjukkan bahwa ikan kemuring yang ditangkap dari alam ketika dipindahkan ke wadah pemeliharaan pada umumnya ikan mengalami stres dan mati dalam waktu tiga sampai tujuh hari. Domestikasi ikan ini penting dilakukan untuk memudahkan proses pengembangannya yang diawali dengan mempertahankan ikan tetap hidup, makan, dan tumbuh pada wadah terkontrol.

Kondisi ikan kemuring yang mengalami stres dan kematian pada saat dipelihara pada wadah terkontrol diduga karena kondisi media budidaya tidak sesuai dengan habitat lingkungan hidupnya. Penurunan kualitas air akan mengakibatkan ikan menjadi stres sehingga menyebabkan terjadinya gangguan fisiologis, perubahan tingkah laku, menghambat pertumbuhan, dan dapat menyebabkan kematian (Lestari $\&$ Syukriah, 2020). Air merupakan media atau habitat yang paling penting bagi kehidupan ikan, selama masa pemeliharaan kualitas air merupakan kunci awal keberhasilan budidaya.
Domestikasi adalah kegiatan mengadaptasikan ikan alam (wild species) terhadap lingkungan baru seperti kolam, bak, pakan buatan, penanganan (handling), dan penanganan secara terkontrol. Domestikasi ini bertujuan agar ikan menyesuaikan diri dengan kondisi lingkungan baru secara terkontrol dan responsif terhadap pakan buatan sehingga dapat tumbuh dan berkembang, serta matang telur dan dapat dipijahkan (Gustiano et al., 2013). Domestikasi dapat meningkatkan jumlah ikan dari alam pada kegiatan budidaya (Teletchea, 2019). Kemampuan ikan kemuring untuk hidup dan tumbuh pada wadah terkontrol dalam lingkungan hidup yang baru merupakan tahap awal dari kegiatan domestikasi yang penting untuk dilakukan penelitian. Penelitian ini bertujuan untuk menguji sintasan dan performa pertumbuhan ikan kemuring yang dipelihara pada akuarium.

\section{BAHAN DAN METODE}

\section{Sumber Ikan dan Metode Penelitian}

Ikan kemuring yang digunakan pada penelitian ini sebanyak 30 ekor. Ukuran panjang ikan yang digunakan yaitu 63-65 mm dengan bobot sebesar 3-4 g/ekor. Ikan kemuring didapatkan dari aliran sungai yang bertempat di Desa Pangkal Buluh, Kecamatan Payung, Kabupaten Bangka Selatan. Metode penelitian yang digunakan yaitu metode eksperimen. Pada metode ini ikan kemuring yang hidup liar di perairan alam, diuji cobakan hidup di wadah terkontrol. Hal ini bertujuan untuk melihat kemampuan ikan kemuring hidup dan berkembang di luar habitat aslinya.

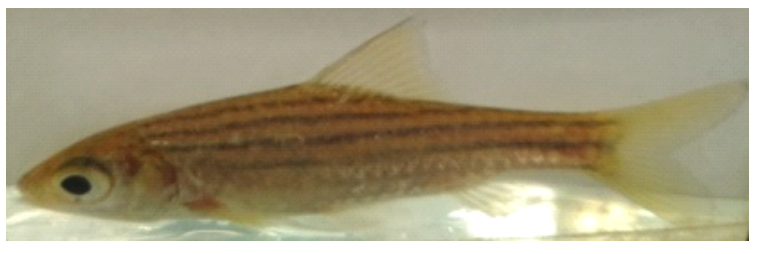

Gambar 1. Ikan kemuring asal perairan Bangka

Figure 1. Kemuring fish from the waters of Bangka

\section{Pemeliharaan Ikan}

Ikan kemuring yang ditangkap dari alam dipelihara dan diadaptasikan di wadah pemeliharaan. Proses pengadaptasian dilakukan menggunakan air sungai selama tujuh hari dalam kondisi diberikan aerasi agar ikan tidak mengalami stres berlebih. Selama proses pengadaptasian ikan diberi pakan alami berupa cacing sutera dan mulai diadaptasikan dengan pakan buatan komersil ikan hias pada hari ketiga. Ikan kemuring yang telah diadaptasikan kemudian dimasukkan ke 
dalam akuarium dengan sumber media air sumur yang sudah diaerasi selama 24 jam. Jumlah akuarium yang digunakan untuk pemeliharaan sebanyak tiga unit yang masing-masing berukuran $40 \mathrm{~cm} \times 40 \mathrm{~cm} \times 40 \mathrm{~cm}$. Masing-masing akuarium disebar sebanyak 10 ekor ikan. Selama pemeliharaan dilakukan proses aerasi pada media pemeliharaan. Ikan kemuring selama proses pemeliharaannya diberi pakan komersil (pakan tenggelam untuk ikan hias) secara at satiation. Pemberian pakan dilakukan sebanyak tiga kali sehari pada pukul 08.00, 12.00, dan 16.00 WIB. Pergantian air pada akuarium dilakukan sebanyak 50\%setiap 10 hari. Waktu pemeliharaan yang dilakukan selama 40 hari.

\section{Parameter Uji}

Parameter uji yang diamati pada penelitian ini yaitu sintasan (survival rate), pertumbuhan bobot mutlak, pertumbuhan panjang mutlak, laju pertumbuhan spesifik, dan kualitas air. Kualitas air yang diukur yaitu oksigen terlarut (dissolved oxygen/DO), pH, total dissolved solid (TDS), suhu, dan total ammonia nitrogen (TAN). Alat ukur yang digunakan terhadap kualitas air tersebut masing-masing yaitu DO meter, $\mathrm{pH}$ meter, TDS meter, termometer, dan amonia checker (peralatan titrasi digital). Nilai hasil pengamatan parameter diolah dan dicantumkan sebagai nilai rataan.

\section{Analisis Data}

Data yang didapatkan dianalisis secara deskriptif kuantitatif. Sintasan ikan kemuring diuji hubungannya dengan parameter kualitas air selama pemeliharaan untuk mengetahui parameter kualitas air yang paling memengaruhi sintasan. Analisis yang digunakan yaitu principal componen analysis (PCA) dengan menggunakan software XLSTAT 2020. Hasil olahannya berupa matriks dan grafik korelasi yang menunjukkan hubungan antar kedua varibel dengan penjelasan yang lebih rinci.

\section{HASIL DAN BAHASAN}

Hasil penelitian menunjukkan bahwa ikan kemuring mampu hidup dalam wadah yang terkontrol dengan tingkat sintasan sebesar 93,33 \pm 0,06\% Sintasan ikan kemuring selama 40 hari tersaji pada Tabel 1. Pengamatan pertumbuhan bobot mutlak, pertumbuhan panjang mutlak dan laju pertumbuhan spesifik menunjukkan bahwa ikan dapat tumbuh dan berkembang (Tabel 1 ).

Tingkat sintasan ikan sebesar 93,33 $\pm 0,06 \%$ merupakan tingkat sintasan yang baik berdasarkan kategori yang dibuat oleh Darmawan et al. (2018). Kategori sintasan tersebut terbagi atas sintasan baik dengan nilai e" 50\% sintasan sedang dengan nilai 30\%
$50 \%$ dan sintasan kurang dengan nilai kurang dari 30\% Tingginya sintasan ikan kemuring disebabkan kualitas air pada media pemeliharaan sesuai dan mendukung sintasan ikan. Selain itu, ikan kemuring yang bersumber dari tangkapan alam telah diadaptasikan terlebih dahulu sehingga mampu beradaptasi dengan lingkungan yang baru. Beberapa faktor-faktor lain yang mendukung sintasan ikan kemuring yaitu proses aerasi selama pemeliharaan yang mampu menjaga keberadaan oksigen terlarut, padat tebar yang sesuai dengan ukuran wadah pemeliharaan, pemberian pakan yang sesuai dan pergantian air secara rutin setiap 10 hari untuk membuang sisa metabolit ikan dan sisa pakan yang tidak termakan. Daya adaptasi ikan terhadap lingkungan (kualitas air) dan makanan merupakan faktor utama yang mendukung sintasan ikan (Nurhuda et al., 2018).

Effendie (2002) menyatakan bahwa faktor yang memengaruhi tinggi rendahnya sintasan adalah faktor abiotik dan biotik. Faktor abiotik terdiri atas parameter fisika dan kimia perairan sedangkan faktor biotik di antaranya yaitu kompetitor, kepadatan populasi, umur dan kemampuan adaptasi organisme. Upaya peningkatan sintasan dapat dilakukan dengan mempertahankan parameter-parameter kualitas air, di antaranya: suhu, oksigen terlarut, $\mathrm{pH}$, amonia, dan lain sebagainya, serta mengadaptasikan ikan pada baru dan menjaga padat tebar pada wadah pemeliharaan. Kualitas air yang baik untuk kehidupan ikan ditandai dengan kandungan oksigen yang cukup dan kadar buangan metabolit (amonia) yang rendah (Bhatnagar \& Devi, 2013).

Pertumbuhan bobot mutlak, panjang mutlak, dan laju pertumbuhan spesifik pada ikan kemuring yang dipelihara selama 40 hari masing-masing sebesar 1,70 $\pm 0,31 \mathrm{~g} ; 10,29 \pm 1,02 \mathrm{~mm}$; dan 0,96 $\pm 0,19 \%$ bobot tubuh/hari. Proses pertumbuhan ikan kemuring ini terlihat cukup optimal bila dibandingkan dengan penelitian sejenis pada ikan Puntius sp. Penelitian Addini et al. (2017) pada ikan Puntius tetrazona selama 40 hari menunjukkan pertumbuhan bobot mutlak, panjang mutlak, dan pertumbuhan spesifik yang tertinggi masing-masing sebesar $0,59 \pm 0,07 \mathrm{~g}, 10,20$ $\pm 0,6 \mathrm{~mm}$, dan $1,94 \pm 0,15 \%$ Ritonga (2020) yang meneliti ikan Puntius binotatus menunjukkan pertumbuhan bobot mutlak dan pertumbuhan spesifik yang tertinggi masing-masing sebesar $0,608 \mathrm{~g}$ dan $1,018 \%$

Optimalnya pertumbuhan ikan kemuring ini menunjukkan bahwa ikan kemuring mampu hidup dan mengkonsumsi jenis pakan komersil yang diberikan.Pakan komersil yang diberikan berupa pakan tenggelam yang menyesuaikan dengan kebiasaan dan tingkah laku ikan yang hidup didekat dasar 
Tabel 1. Sintasan, pertumbuhan bobot mutlak, laju pertumbuhan spesifik, pertumbuhan panjang mutlak ikan kemuning dalam akuarium selama 40 hari

Table 1. Survival, absolute weight growth, specific growth rate, absolute length growth of lined barbreared in aquarium for 40 days

\begin{tabular}{|c|c|c|c|c|c|c|c|}
\hline \multirow{3}{*}{$\begin{array}{l}\text { Pengamatan } \\
\text { Observation }\end{array}$} & \multicolumn{6}{|c|}{$\begin{array}{l}\text { Nilai rataan pengamatan parameter selama pemeliharaan } \\
\text { The average value of parameter observations during fish rearing }\end{array}$} & \multirow{3}{*}{$\begin{array}{c}\text { Nilai } \\
\text { rataan } \\
\text { Average } \\
\text { value }\end{array}$} \\
\hline & \multicolumn{2}{|c|}{$\begin{array}{l}\text { Jumlah (ekor) } \\
\text { Amount }\end{array}$} & \multicolumn{2}{|c|}{$\begin{array}{l}\text { Bobot } \\
\text { Weight (g) }\end{array}$} & \multicolumn{2}{|c|}{$\begin{array}{l}\text { Panjang } \\
\text { Length }(\mathrm{mm})\end{array}$} & \\
\hline & $\begin{array}{l}\text { Awal } \\
\text { Initial }\end{array}$ & $\begin{array}{l}\text { Akhir } \\
\text { Final }\end{array}$ & $\begin{array}{l}\text { Awal } \\
\text { Initial }\end{array}$ & $\begin{array}{l}\text { Akhir } \\
\text { Final }\end{array}$ & $\begin{array}{l}\text { Awal } \\
\text { Initial }\end{array}$ & $\begin{array}{l}\text { Akhir } \\
\text { Final }\end{array}$ & \\
\hline Sintasan (Survival rate ) $(\%$ & 10 & $9 \pm 0.58$ & & & & & $93.33 \pm 0.06$ \\
\hline $\begin{array}{l}\text { Pertumbuhan bobot mutlak } \\
\text { Absolute weight growth }(\mathrm{g})\end{array}$ & & & $3.61 \pm 0.15$ & $5.31 \pm 0.24$ & & & $1.70 \pm 0.31$ \\
\hline $\begin{array}{l}\text { Laju pertumbuhan spesifik } \\
\text { (\%bobot tubuh/hari) } \\
\text { Specific growth rate } \\
\text { (\%body weight/days) }\end{array}$ & & & $3.61 \pm 0.15$ & $5.31 \pm 0.24$ & & & $0.96 \pm 0.19$ \\
\hline $\begin{array}{l}\text { Pertumbuhan panjang mutlak } \\
\text { Absolute length growth (mm) }\end{array}$ & & & & & $63.31 \pm 1.7$ & $59 \pm 0.88$ & $10.29 \pm 1.02$ \\
\hline
\end{tabular}

perairan.Ukuran pakan sesuai dengan ukuran bukaan mulut ikan. Komposisi pakan komersil yang digunakanyaitu protein $48 \%$ BETN 20\% lemak $6 \%$ serat $3 \%$ abu $12 \%$ dan kadar air $11 \%$ Komposisi nutrisi tersebut terutama kandungan proteinnya, mendukung pertumbuhan ikan kemuring.Kecukupan jumlah nutrisi di dalam pakan tidak hanya mampu memberikan energi untuk kegiatan metabolisme tubuh ikan, tetapi juga mampu memenuhi kebutuhan ikan untuk tumbuh (Niode et al., 2017). Pertumbuhan ikan dapat terjadi jika jumlah nutrisi pakan yang dicerna dan diserap oleh ikan lebih besar dari jumlah yang diperlukan untuk pemeliharaan tubuhnya.

Kemampuan ikan dalam beradaptasi dan kondisi lingkungan yang sudah sesuai menjadikan ikan berada dalam kondisi yang sehat dan tidak stress sehingga sumber protein dari pakan dimanfaatkan secara optimal untuk pembentukan jaringan yang terpusat terhadap energi pertumbuhan. Prabu et al., (2017) menyatakan bahwa energi yang dibutuhkan oleh seekor ikan pada dasarnya berasal dari protein pakan yang digunakan untuk pertumbuhan dan pemeliharaan tubuh.Protein merupakan faktor terpenting yang berkontribusi pada kinerja pertumbuhan spesies yang dibudidayakan. Ikan akan dapat melangsungkan hidupnya dengan baik jika mendapatkan pakan yang berukuran tepat dengan ukuran bukaan mulutnya ((Zulkhasyni et al., 2017). Kondisi kualitas air yang terkontrol sehingga kualitas airnya tidak mengalami degradasi menjadikan pemanfaatan terhadap pakan yang diberikan optimal untuk pertumbuhan. Hixson (2014) menyatakan peningkatan pertumbuhan terjadi pada saat tingginya pemanfaatan pakan yang sesuai dengan kebutuhan ikan yang dipelihara. Menurut Bajaj (2017), pertumbuhan ikan sangat dipengaruhi oleh kondisi lingkungan perairan. Faktor-faktor lingkungan yang memengaruhi pertumbuhan ikan di antaranya yaitu parameter fisika, kimia, dan nutrien anorganik.

\section{Kualitas Air}

Kualitas air memegang peranan penting dalam memengaruhi sintasan dan pertumbuhan ikan. Hasil pengukuran kualitas air pada wadah pemeliharaan selama 40 hari penelitian dapat dilihat pada Tabel 2.

Selama proses pemeliharaan, parameter kualitas air yang terukur di antaranya suhu, pH, DO, TDS, TAN, dan kesadahan. Nilai parameter kualitas air suhu, pH, dan DO berada dalam nilai yang sesuai dengan habitat ikan tersebut di alam. Nilai TDS, TAN, dan kesadahan memiliki nilai yang berbeda dengan kondisi di habitat alam namun masih mendukung sintasan ikan kemuring. Hal ini terlihat dari tingkat sintasan selama pemeliharaan pada Tabel 1 yang menunjukkan tingginya tingkat sintasan ikan kemuring yaitu sebesar $93,33 \pm 0,06 \%$

Kualitas air merupakan faktor utama yang menentukan sintasan, pertumbuhan, proses-proses 
Tabel 2. Kualitas air di akuarium pemeliharaan ikan kemuring

Table 2. Average values of water quality of lined barbs' rearing media

\begin{tabular}{lccc}
\hline \multicolumn{1}{c}{$\begin{array}{c}\text { Parameter } \\
\text { Variables }\end{array}$} & $\begin{array}{c}\text { Rata-rata kualitas air } \\
\text { di habitat alam } \\
\text { Average of water quality in } \\
\text { natural habitats }\end{array}$ & $\begin{array}{c}\text { Kisaran kualitas air } \\
\text { selama pemeliharaan } \\
\text { Range of water quality } \\
\text { in aquarium }\end{array}$ & $\begin{array}{c}\text { Rata-rata kualitas air } \\
\text { selama pemeliharaan } \\
\text { Average water quality } \\
\text { during fish rearing }\end{array}$ \\
\hline $\begin{array}{l}\text { Suhu (Temperature) }\left({ }^{\circ} \mathrm{C}\right) \\
\text { pH }\end{array}$ & $28.67 \pm 0.58$ & $28-29$ & $28.72 \pm 0.44$ \\
Oksigen terlarut & $4.83 \pm 0.35$ & $5.33-7.73$ & $6.28 \pm 0.82$ \\
Dissolved oxygen [D0] (mg/L) & $4.99 \pm 0.11$ & $5.32-6.83$ & $5.81 \pm 0.77$ \\
Total dissolved solid [TDS] (mg/L) & $0.10 \pm 0.01$ & $0.24-0.68$ & $0.48 \pm 0.16$ \\
Total ammonia nitrogen [TAN] (mg/L) & 0 & $0.47-3.00$ & $2.50 \pm 1.01$ \\
Kesadahan (Hardness) (mg/L) & $265 \pm 7.07$ & $70-220$ & $106.67 \pm 55.73$ \\
\hline
\end{tabular}

fisiologi dalam tubuh ikan (Dineshkumar et al., 2017). Setiap spesies ikan memiliki persyaratan nilai kualitas air yang berbeda-beda untuk kebutuhan hidupnya. Kualitas air yang baik untuk kehidupan ikan ditandai dengan kandungan oksigen yang cukup dan kadar buangan metabolit (amonia) yang rendah (Bhatnagar \& Devi, 2013). Karakteristik parameter kualitas air yang menonjol dari ikan kemuring yaitu mampu hidup pada $\mathrm{pH}$ asam dan basa. Ikan ini mampu hidup pada kisaran pH 5,33-7,73.

\section{Hubungan Sintasan Ikan dengan Kualitas Air}

Sintasan ikan sangat dipengaruhi oleh kualitas air. Bentuk hubungan antara sintasan dan kualitas air dianalisis dengan menggunakan PCA yang tersaji pada Gambar 2.
Gambar 2 menunjukkan bahwa terdapat komponen F-1 dan F-2 yang merupakan nilai eigen. Nilai ini karakteristik suatu matriks yang menentukan jumlah komponen yang digunakan. Setyaningsih et al. (2010) menyatakan bahwa penentuan jumlah komponen pada matriks dan grafik memerlukan nilai eigen untuk menerangkan keragaman komponen utama. Menurut Supranto (2004), syarat minimum yang harus dipenuhi untuk menentukan banyaknya komponen yang diambil adalah apabila varian komulatifnya mencapai minimal $60 \%$ atau $75 \%$ Nilai F-1 dan F-2 pada Gambar 2 sebesar $61,28 \%$ yang menunjukkan hubungan antara variabel dapat mewakili kondisi hubungan yang sebenarnya.

Pengukuran kualitas air yang dihubungkan dengan sintasan menggunakan principal component analysis (PCA) menghasilkan korelasi parameter TDS terhadap

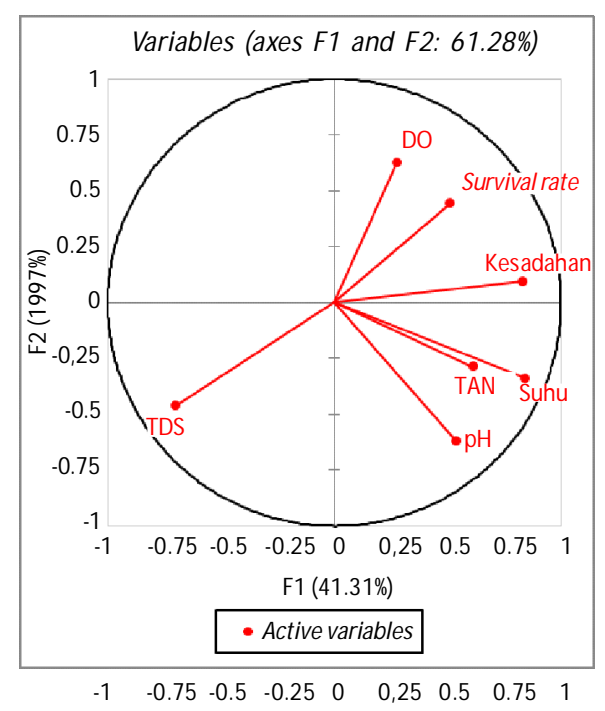

Gambar 2. Hubungan sintasan dengan kualitas air.

Figure 2. Relationship between survival rate and water quality of lined barbs during early domestication in an aquarium setting. 
Tabel 3. Nilai korelasi PCA antara sintasan dengan kualitas air

Table 3. Correlation of PCA between survival rate and water qualityof lined barbs during early domestication in an aquarium setting

\begin{tabular}{lcc}
\hline \multicolumn{1}{c}{$\begin{array}{c}\text { Parameter } \\
\text { Variables }\end{array}$} & $\begin{array}{c}\text { Nilai korelasi } \\
\text { The val ue of correlation }\end{array}$ & $\begin{array}{c}\text { Interpretasi } \\
\text { Interpretation }\end{array}$ \\
\hline Suhu (Temperature) $\left({ }^{\circ} \mathrm{C}\right)$ & 0,844 & Sangat kuat (Very strong) \\
$\mathrm{pH}$ & 0,54 & Kuat (Strong) \\
Oksigen terlarut (Dissolved oxygen ) $[\mathrm{DO}](\mathrm{mg} / \mathrm{L})$ & 0,276 & Cukup (Moderate) \\
Total dissolved solid $[\mathrm{TDS}](\mathrm{mg} / \mathrm{L})$ & $-0,699$ & Kuat (Strong) \\
Total ammonia nitrogen $[\mathrm{TAN}](\mathrm{mg} / \mathrm{L})$ & 0,612 & Kuat (Strong) \\
Kesadahan (Hardness) $(\mathrm{mg} / \mathrm{L})$ & 0,829 & Sangat kuat (Very strong) \\
\hline
\end{tabular}

Keterangan (Note): Acuan interpretasi nilai korelasi (Reference): Sarwono (2011)

$0=$ tidak ada korelasi (no correlation)

0.00-0.25 = korelasi sangat lemah (very weak correlation)

$0.25-0.50=$ korelasi cukup (moderate correlation)

0.50-0.75 = korelasi kuat (strong correlation)

0.75-0.99 $=$ korelasi sangat kuat (very strong correlation)

$1=$ korelasi sempurna (perfect correlation)

sintasan tergolong negatif dengan membentuk sudut $>90^{\circ}$ yang berarti bahwa TDS tidak terlalu berpengaruh terhadap sintasan ikan kemuring. Sementara hubungan suhu, pH, DO, TAN, dan kesadahan terhadap sintasan tergolong positif dengan membentuk sudut $<90^{\circ}$ sehingga parameter tersebut sangat berpengaruh terhadap kualitas air.

Korelasi antar parameter kualitas air dengan sintasan pada Tabel 2 menunjukkan bahwa sintasan ikan kemuring dipengaruhi oleh suhu, pH, DO, TAN, dan kesadahan. Parameter TDS memiliki korelasi negatif yang kuat. Di antara parameter kualitas air yang berpengaruh terhadap sintasan, parameter yang korelasinya sangat kuat yaitu suhu dan kesadahan.

\section{KESIMPULAN}

Ikan kemuring dapat beradaptasi dengan baik, mampu hidup, dan tumbuh dalam akuarium. Pemeliharaan ikan kemuring selama 40 hari pada wadah akuakultur mampu menghasilkan sintasan, pertumbuhan bobot mutlak, pertumbuhan panjang mutlak, dan laju pertumbuhan. Parameter kualitas air yang memengaruhi sintasan ikan kemuring yaitu suhu, pH, DO, TAN, dan kesadahan sedangkan parameter TDS tidak memengaruhi sintasan ikan kemuring.

\section{UCAPAN TERIMA KASIH}

Terima kasih kepada Program Studi Akuakultur, Universitas Bangka Belitung atas fasilitas, sarana, dan prasarana yang mendukung penelitian ini.

\section{DAFTAR ACUAN}

Addini, N., Pamukas, N.A., Mulyadi, \& Sukarman. (2017). Peningkatan kualitas warna dan pertumbuhan ikan Albino tiger barb (Puntius tetrazona) dengan pemberian pakan yang mengandung tepung udang rebon. Berkala Perikanan Terubuk, 45(3), 44-56.

Bajaj, S. (2017). Effect of environmental factors on fish growth. Indian J. Sci. Res., 12(2), 87-91.

Bhatnagar, A. \& Devi, P. (2013). Water quality guidelines for the management of pond fish culture. International Journal of Evironmental Sciences, 3(6), 198-2009.

Darmawan, J., Tahapari, E., \& Suharyanto. (2018). Kinerja pertumbuhan ikan patin siam (Pangasianodon hypophthalmus Sauvage, 1878) hasil seleksi di KJA Waduk Darma Kuningan, Jawa Barat. LIM NOTEK Perairan Darat Tropis di Indonesia, 25(2), 88-96.

Dineshkumar, G., Karthik, M., \& Rajakumar, R. (2017). Study of seasonal water quality assessment and fish pond conservation in Thanjavur, Tamil Nadu, India. Journal of Entomology and Zoology Studies, 5(4), 1232-1238.

Effendie, M.I. (2002). Biologi perikanan. Yogyakarta, ID: Yayasan Pustaka Nusatama.

Gustiano, R., Kontara, E.K., Wahyuningsih, H., Subagja, J., Asih, S., \& Saputra, A. (2013). Domes- 
tication mahseer (Tor soro) in Indonesia. Communication in Agricultural and Applied Biological Sciences, 78(4), 165-168.

Lestari, D.F. \& Syukriah. (2020). Manajemen stres pada ikan untuk akuakultur berkelanjutan. Jurnal Ahli Muda Indonesia, 1(1), 96-105.

Hixson, S.M. (2014). Fish nutrition and current issues in aquaculture: The balance in providing safe and nutritious seafood, in an environmentally sustainable manner. Journal of Aquaculture Research \& Development, 5(3), 1-10.

Muslih, K., Adiwilaga, E.M., \& Adiwibowo, S. (2014). Karakteristik habitat dan keanekaragaman ikan air tawar sungai menduk yang mendapat pengaruh penambangan timah di Kabupaten Bangka. AKUATIK-Jurnal Sumberdaya Perairan, 8(2), 17-23.

Niode, A.R., Nasriani, \& Irdja, A.M. (2017). Pertumbuhan dan kelangsungan hidup benih ikan nila (Oreochromis niloticus) pada pakan buatan yang berbeda. Akademika, 6(2), 99-112.

Nurhuda, A.M., Samsundari, S., \& Zubaidah, A. (2018). Pengaruh perbedaan interval waktu pemuasaan terhadap pertumbuhan dan rasio efisiensi protein ikan gurame (Osphronemus gouramy). Acta Aquatica, 5(2), 59-63.

Prabu, E., Felix, S., Felik, N., Ahilan, B., \& Ruby, P. (2017). An overview on significance of fish nutri- tion in aquaculture industry. International Journal of Fisheries and Aquatic Studies, 5(6), 349-355.

Ritonga, L.B.R. (2020). Pengaruh padat tebar yang berbeda terhadap laju pertumbuhan ikan wader cakul (Puntius binotatus). Jurnal Chanos chanos, 18(1), 1-6.

Said, D.S. \& Hidayat. (2015). 101 ikan hias air tawar Nusantara. Jakarta, ID: LIPI Press, $238 \mathrm{hlm}$.

Sarwono, J. (2011). Mixed methods: Cara menggabung riset kuantitatif dan riset kualitatif secara benar. Jakarta, ID: PT Elex Media Komputindo, 207 hlm.

Setyaningsih, D., Apriyantono, A., \& Sari, M.P. (2010). Analisis sensori untuk industri pangandan agro. Bogor, ID: IPB Press, $180 \mathrm{hlm}$.

Supranto, J. (2004). Analisis multivariat arti dan interpretasi. Jakarta, ID: Rieka Cipta. Jakarta, 359 hlm.

Teletchea, F. (2019). Fish domestication: An overview. In Teletchea, F. Animal Domestication. p. 1-21. France: Intech Open.

Zulkhasyni, Adriyeni, \& Utami, R. (2017). Pengaruh dosis pakan pelet yang berbeda terhadap pertumbuhan ikan nila merah (Oreochromis sp.). Jurnal Agroqua, 15(2), 35-42. 